Journal of Development and Communication Studies, Vol. 6. No. 1, January - June 2019

ISSN (Online \& Print): 2305-7432.

http://www.devcomsjournalmw.org.

\title{
SME Development Policies of Tanzania and Rwanda: Comparability of Policy Presentation on Focus, Significance, Challenges and Participation
}

\author{
Freddy Jirabi Gamba, Department of Management Science, Institute of Finance Management (IFM), Dar es \\ Salaam,Tanzania gamba.freddy@,ifm.ac.tz and capacitybuilding.gamba@,gmail.com
}

\begin{abstract}
The world's new ideologies of regionalisationism and globalizationism anchor on the role of Small and Medium Enterprises (SMEs) for promotion of a healthy business climate for upgrading the private sector and engineering for economic efficiency and development. SMEs have been a mechanism of inclusion and equity for economic empowerment and deepening of economic and business services especially in developing countries. The SMEs'cultural and socio-economic importance has driven the initiation of national SME development in many countries. SMEs have gained elevating importance in developed and developing economies, have the capability of quick adaptation, low cost of management, less capital and sometimes labor intensive for enabling cheap production. Despite their size related weaknesses, SMEs are less affected by economic crises due to their inherent flexibility and adaptability characteristics. SMEs are vital actors for enhancing entrepreneurial innovation and innovation system as well as competitiveness in economies. National SME development policies, being high level political intent, directives and guidelines are critical for development, coordination and deployment of potential and available resources and capabilities. The paper, therefore, aims at analyzing and comparing the presentations of SME development policies of Tanzania and Rwanda based on policy framework options namely, focus, significance, challenges and participation. The findings show elevating differences in various spheres of the policy processes including the SME definition, vision, mission and objectives in terms of activeness in presentation, political flavour, sharpness of intent and sense of anticipated commitment. This implies a continued gap of SME development between countries under review and other East African Community (EAC) member countries until policies affecting SMEs are harmonized.
\end{abstract}

Keywords: SMEs, Policy Presentation, Policy Framework, Entrepreneurship, BDS, Tanzania, Rwanda

https://dx.doi.org/10.4314/jdcs.v6i1.1

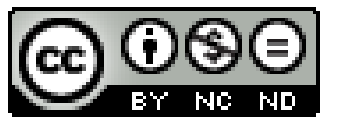

(C) 2019. The Author. This work is licensed under the Creative Commons Attribution 4.0 International License (CC-ByNC-ND). Users may freely share and redistribute this work provided that the author and the Journal of Development and Communication Studies are fully acknowledged. Users may not tweak or remix and offer this work for sale. The full license may be accessed at https://creativecommons.org/licenses/by-nc-nd / $4.0 /$

\section{Introduction}

National and sector policy comparison between and within countries has been a research area over the years; the same policy has been compared between countries or different policies within a country (Moharir, 1986; Hanekom, 1987; Fontanine et al, 2006; Ikelegbe, 2006; Thomas, 2007; Miles, 2012). Most policy comparative studies have been global and multilateral focusing on assessment of policy formulation, implementation processes and results (Miles, 2012), policy presentation had lacked attention wholesomely. In Mooij \& de Vos (2003), out of 132 annotated bibliographies on policy 
processes, only one, Horowitz (1989), worked on policy presentation. Horowitz differentiated policy presentation focus between developed and developing countries and asserts that different from the former, the later policies are meant to enhance regime legitimacy and political intimacy than humancentred development considerations. Conversely, this article focuses on two countries belonging to the East African Community (EAC) and compares the presentation of SME policies. Table 1 displays literature on policy processes.

Table 1: Literature on Policy Processes

\begin{tabular}{|c|c|c|}
\hline Policy Area & Area or Process Features & Source \\
\hline $\begin{array}{l}\text { 1. Policy } \\
\text { presentation } \\
\text { (document) }\end{array}$ & $\begin{array}{l}\text { - Layout and Content } \\
\text { - Clarity, Meanings \& Political Intents } \\
\text { - Matrices of Roles on Policy Process }\end{array}$ & Horowitz, 1989; Moiij \& de Vos, 2003 \\
\hline $\begin{array}{l}\text { 2. Policy } \\
\text { formulation }\end{array}$ & $\begin{array}{l}\text { - Meetings, Dialogue \& Participation } \\
\text { - Consulting }\end{array}$ & $\begin{array}{l}\text { Simon, 1976; John and Mendizal, 2009; Ikelegbe, } \\
\text { 2006; Yang et al., 2014; Fontanine et al,. 2006; } \\
\text { Jensen, 2001. }\end{array}$ \\
\hline $\begin{array}{l}\text { 3. Policy } \\
\text { implementation }\end{array}$ & $\begin{array}{l}\text { - All policy formulation features } \\
\text { - Contracting, Reward/appreciation }\end{array}$ & $\begin{array}{l}\text { Goodluck et al,. 2016). Michael et al., 2011; Miles, } \\
2012 \text { Mitroff, 1983; Thomas, 2007; Simon, } 1976\end{array}$ \\
\hline $\begin{array}{l}\text { 4. Policy } \\
\text { monitoring }\end{array}$ & $\begin{array}{l}\text { - All policy implementation featuers } \\
\text { - Punitive measures }\end{array}$ & $\begin{array}{l}\text { Miles, 2011; Ikelegbe, } 2006 \text { Yang et al., 2014; } \\
\text { Fontanine et al, 2006; Mitroff, 1983; Thomas, } 2007\end{array}$ \\
\hline
\end{tabular}

Source: Author compiled, 2018

The importance of SMEs in EAC is presented in Article 6 on the operational principles of the EAC, Article 127-128 of the EAC Treaty (1999) and Para. 137 of the EAC Development Strategy 2009. Trade in EAC largely involves SMEs as it is estimated that 10-30 percent of trade between EAC Partner states is Informal Cross Border Trade (ICBT) done by SMEs (Agalo, 2010; Tantrade, 2017). In developing countries, it is estimated that 90 percent of non-agricultural enterprises are SMEs (Hidayet et al, 2010; Robu, 2013; RoR, 2010). The SME sector plays a predominant economic role in economies and possesses the highest potential in employment generation, enterprise growth, local marketing and exports (Frimpong, 2013; Rutashobya, 2009). SMEs networks are commended as tools of promoting the private sector (Hidayet et al., 2010; Goodluck et al., 2016). Though, it is noted that SMEs and micro enterprises in OECD countries account for over 95 percent of all firms, 60-70 percent of employment and 55 percent of GDP and create the majority of new jobs; their contribution in terms of value addition has not been commendable in sub-Saharan Africa (EOCD, 2013).

For valid socio-economic grounds; governments and SME development agencies provided assistance for the establishment and development of SMEs (OECD, 2012; Maad and Liedholm, 2008). The assistance has included business development services (BDS) such as training and entrepreneurial development, pre-investment feasibility studies, facilities of raw materials and other inputs, infrastructural facilities, product and design advice, domestic and export marketing and finance arrangements. They were also assisted to establish business associations for enhancing jointcollectiveness, information sharing and advocacy (Pedersen, 2003; Goodluck et al,. 2016). According to Abe and Dutta (2014), specific national policy options should base on (1) significance or centrality of SMEs in adding value; (2) critical challenges facing SMEs; and (3) the involvement of stakeholders in policy-making and implementation. The paper aims at analyzing and comparing the national SME development policy 2003 of Tanzania and Rwanda's SME development policy 2010 based on policy framework options. The paper integrates the stakeholders theory and policy formulation theories (WIPO, 2014; Fontanine et al, 2006; Jensen, 2001). Though this article cites the power, legitimacy and urgency model as stakeholders behavioural attributes (Fontanine et al, 2006), its analysis will largely lean on involvement, collaborative, monitoring and defending behaviourial attributes of stakeholders (Yang et al., 2014).

The contribution of this paper is threefold, namely, scope and theoretical. Firstly, as indicated in the table 1, most policy studies have been global and multilateral focusing mainly on assessment of policy processes against policy delivery or results (Simon, 1976; Michael et al., 2011; Miles, 2012), and no 
attention has been given to policy presentation. Secondly, the focused scope of this article is uniquely bilateral involving two neighbouring countries of the same economic block; and thirdly, comparing SME policy presentations had not been attended; with consideration that SME is a prominent and cross cutting sector, succinctly, analysis of presentation on focus, value addition or significance, challenges and participation contributes to available literature. Theoretically, there is the integration of stakeholder theory and policy formulation theories, which is validly new theoretical blending. The paper is organized to provide (i) Overview of SMEs in Tanzania and Rwanda (ii) Theoretical Framework and Literature Review (iii) methodology of the study; (iv) the findings; and (v) conclusion and policy implications.

\section{Overview of SMEs in Tanzania and Rwanda}

\section{Definitions of SME}

There is no universally accepted definition for SMEs as different countries use various measures or parameters of size, depending on their level of development and purpose (Hidayet et al., 2010). The commonly used yardsticks are number of employees, total investment and annual sales turnover (ibid.). Such variations make inter-country comparisons very difficult even when data are available. Qualitatively, SME is one in which all relatively important administrative and managerial decisions are made by one or two owners-entrepreneurs, little or no specialization, lack of book-keeping, among others (ILO, 1972). Quantitatively, the number of employees, capital invested, turnover or a combination of the two or more of them have been used. The World Bank defines SME as an enterprise which at micro scale employs less than 50 people, at small scale employs 50 and at medium scale employs between 50-200 employees (Maad and Liedholm, 2008). In Ireland, the upper limit for SMEs is 50 employees, whereas in the Netherlands it is 100 employees. In France even enterprises with 1,000 workers are categorized as SME (Lukacs, 2005). The European Union (EU) defines small enterprises as those employing less than 50 and with not more than 7 million Euro annual turnovers. Middle-scale enterprises employ less than 250 employees with not more than 40 million Euro annual turnover (Hidayet et al, 2010; EC, 2009). In 2003, with consideration of increased inflation and productivity, the EU revisited its SME definition. Table 2 shows the EU definition of SMEs and how it evolved within a decade.

Table 2: Evolving Definition of SME in European Union

\begin{tabular}{|l|l|l|l|l|l|}
\hline \multirow{2}{*}{ SME Category } & \multirow{2}{*}{ Employment } & \multicolumn{3}{l|}{ Turnover (Million Euro) } & \multicolumn{2}{l|}{ Balance Sheet (Million Euro) } \\
\cline { 3 - 6 } & & 1996 & 2005 & 1996 & 2005 \\
\hline Medium & 250 & 40 & 50 & 27 & 43 \\
\hline Small & 50 & 7 & 10 & 5 & 10 \\
\hline Micro & 10 & N/A & 2 & N/A & 2 \\
\hline
\end{tabular}

Source: Hidayet et al (2010) and EC (2009)

The SME definitions' quantitative yardsticks have taken a lower scale in terms of numbers, size and value in sub-Saharan Africa and other developing countries as compared to the developed world. Notably, the definitions of SMEs differ among EAC partner states. Whereas Rwanda and Uganda consider the annual turnover in their definitions, Kenya and Tanzania do not do so. Uganda uses total assets; Kenya uses capital assets excluding property; Rwanda uses net capital investment; and Tanzania uses capital investment in machinery only (RoK, 2010; RoR, 2010; URT,2012b; URT, 2003). Table 2 shows the summarised SME definitions in EAC Partner States.

Table 3: SME definitions in EAC Partner States (monetary figures in millions)

\begin{tabular}{|l|l|l|l|l|l|}
\hline \multirow{2}{*}{ SME Category } & \multicolumn{4}{|l|}{ Rwanda } & Kenya \\
\cline { 2 - 6 } & Workers & Investment (RwF) & Turnover $(\mathrm{RwF})$ & Workers & Capital Assets(Kshs) \\
\hline Micro & $1-3$ & $<0.3$ & $<0.5$ & up to 2 & Not defined \\
\hline Small & $4-30$ & $0.3-12$ & $0.5-15$ & $5-50$ & Not defined \\
\hline Medium & $31-100$ & $12-50$ & $15-75$ & $200+$ & 2 mill \\
\hline
\end{tabular}




\begin{tabular}{|l|l|l|l|l|l|}
\hline \multicolumn{3}{|c|}{ Tanzania } & \multicolumn{3}{c|}{ Uganda } \\
\hline SME Category & Workers & Machinery (Tshs) & Workers & Total Assets (Ug.Shs) & Turnover (Ug.Shs) \\
\hline Micro & $1-4$ & Up to 5 & $1-4$ & Up to 12 & Up to 12 \\
\hline Small & $5-49$ & $5-200$ & $5-50$ & Up to 360 & Up to 360 \\
\hline Medium & $50-99$ & 200 to 800 & $50+$ & $360+$ & $360+$ \\
\hline
\end{tabular}

Source: URT (2003), EAC-SPD (2006)

\section{SMEs in Tanzania}

A review of the Tanzania SME Development Policy of 2003 estimates the number of SMEs in the country to be more than 3 million employing more than 5.2 million people, 45 percent of whom are located in urban and peri-urban areas and 55 percent in rural areas (Oyen and Gedi, 2013). The estimated size of the informal economy as a percentage of GDP had decreased over time: from 62.5 percent in 1991 to 43.6 percent in 2005 and 39.7 percent in 2010; and the estimated size of the informal sector as a percentage of GDP excluding agriculture is lower and moved from 43.1 percent in 1991 to 30.1 percent in 2005 and 27.4 percent in 2010 (ibid.). Most SMEs are labour-intensive, they create employment at relatively low levels of investment per job created. Thus, they have contributed in employment creation, served as a training ground for entrepreneurship and management for young people and new entrants (URT, 2003). SMEs are based on sub-sectors, major activities, major products and services, and their location. The Tanzanian SMEs were allocated to various sectors according to the International Standard for Industrial Classification (ISIC) as presented in Table 4.

Table 4: SMEs in Tanzania by Sector

\begin{tabular}{|l|c|c|}
\hline \multicolumn{1}{|c|}{ International Standard for Industrial Classification (ISIC) Sector } & Number & percent \\
\hline Agriculture, forestry, and fishing & 13178 & 0.4 \\
\hline Mining and quarrying & 3684 & 0.1 \\
\hline Manufacturing & 429050 & 13.6 \\
\hline Electricity, gas, steam, air conditioning supply & 9849 & 0.3 \\
\hline Water supply, sewerage and waste management & 1843 & 0.1 \\
\hline Wholesale, retail trade, repair of motor vehicles & 1750897 & 55.4 \\
\hline Transportation and storage & 14404 & 0.5 \\
\hline Accommodation and food service activities & 836564 & 26.4 \\
\hline Information and communication & 1791 & 0.1 \\
\hline Professional scientific and technical activities & 9845 & 0.3 \\
\hline Administrative and support service activities & 8742 & 0.3 \\
\hline Public administration, defense, social security & 2670 & 0.1 \\
\hline Other service activities & 80370 & 2.5 \\
\hline Total & 3162887 & 100.0 \\
\hline
\end{tabular}

Source: URT (2012b), National Baseline Survey, MIT and FSDT

\section{SMEs in Rwanda}

In Rwanda, SME accounts for 41 percent of all private sector employment. SMEs are about 98 percent of all enterprises and provide 84 percent of private employment. Despite all the escalating achievements, Rwanda's private sector, and SMEs in particular have been facing a lot of challenges. According to GTZ Study (2008) and OTF/PSF survey (2008), the challenges include high cost of energy and transport, poor business planning and management skills, lack of human capital and human capacity building programs, market information, lack of technical knowledge and training and limited access to finance. The top challenge was high taxes, followed by lack of customer/market knowledge, lack of capital, uncompetitive prices, access to finance and transport. The key challenges to start-up and scale up/ established or existing SMEs were categorically registered. According to the Rwanda Business Operators Census Report (2009) on SMEs, the vast majority of SMEs (93.07 percent) work in commerce and services. This is followed by 1.86 percent in professional services, 1.66 percent in arts \& crafts, 1.33 percent in industry, 0.94 percent in financial services, 0.7 percent in tourism and 0.45 percent in agriculture and livestock. This heavy concentration in the commerce and services sector, with only 1.33 percent in industry, reveals the need to address the challenges faced by SMEs, in order to build an 
economy based on value-added exports. The Rwanda government identified and prioritized 20 SME product clusters, 12 out of them are food processsing related. These clusters are: horticulture, fish, milk, meat, honey, cassava, wheat, wood, fashion and tailoring, essential oil, irish potatoes, eco-tourism, macadamia, spices, handcraft, ceramic and pottery, maize, mineral, precious stones, gem and jewelleries and ICT (PSF, 2004; RoR, 2009).

\section{Theoretical Framework and Literature Review}

\section{Theoretical Perspectives on SME Policy and Stakeholders}

Policy theories include institutional theory, rational theory and garbage-can theory, incremental theory, game scanning theory, process theory, group model and public choice theory (Moharir, 1986; Hanekom, 1987). For policy to influence, various stakeholders are involved, so the need to blend stakeholders theory with policy theories is critical for explaining SME policies across countries (Fontanine et al, 2006). Some theories have SME compatibility weaknesses due to the demanding nature of the sector; institutional theory, for example, is short in that it does not address the society's critical issues to be solved and does not display the value of delivery output and rather concentrates on building enforcement power centres (Moharir, 1986). It is also criticised for being one-way and absence of negotiation on policy issues with stakeholders. For the array of stakeholders and multi-dimensional nature of SME sector, the process model and group model of public policy and the stakeholders theory are valid in this paper (Michael et al., 2011; Goldsmith, 2002; Jensen, 2001).

The process model (PM) focuses on identifying problem, demanding for government action and formulation of proposals by various stakeholders (Ikelegbe, 2006). The model enforces policy legitimation through collaborative selection, enactment, implementation and evaluation of the mutually chosen policies. Despite the criticism that the model is so linear, simplistic and failing to address multiple factors influencing the process (Young et al., 2009), it uses and processes ideas from citizen groups, politicians, think tanks, interested groups, professional associations and non-governmental organisations (NGOs); which ultimately dilute its inherent weakness and bear processed complexities. Additionally, group model (GM) informs that, the main agent of policy change is the interest-groups' initiative whereby they pressure and interact with the policy makers on preferences and self-interest (Thomas, 2007; Simon, 1976). In this vein, the role of the political system is to establish and enforce compromises between various, conflicting interests in the society.

Despite that the process model and group model assume multi-dimensional and interdependent cooperation and diversity of stakeholders (Michael et al., 2011; Miles, 2012). The stakeholers theory, then, defines and synchronizes stakeholders' attributes in the policy process (Mitroff, 1983; Fontanine et al, 2006; Jensen, 2001). The theory gives three typological classifications of stakeholders. (1) Core, Strategic, and Environmental Stakeholders: Core are essential to the survival of the institution; strategic are vital for threats and opportunities; and environmental are all others in the organization's environment. (2) Stakeholder with Legitimacy, Power, and Urgency: Legitimacy is the perceived validity of the stakeholder's claim to a stake; power is the ability or capacity of a stakeholder to produce an effect; and urgency refers to the degree to which the stakeholder's claim demands immediate attention. (3) The Stakeholders' Potential Ability to Threaten or Cooperate: this accounts for involvement, collaborative, monitoring and defending behaviourial attributes of stakeholders (Yang et al., 2014). The theory informs that though an institution has shareholders, there are other actors with their attributes residing within and outside the organisation who contribute to the realization of the vision and mission and define its destiny (Miles, 2011).

\section{The Framework for SME Development Policy}

The WIPO annual documents and deliberations subtly give criteria for effective national and sector policies (www.wipo.org). In line with WIPO multi-dimensional socio-political and economic innovations, Abe and Dutta (2014) enlists the specific national policy options for SMEs developmentcentred actions based on: (1) focus on SME specificity and objectivity (2) the centrality of SMEs in 
adding value (GII, 2015); (3) critical challenges in SME development to create an enabling environment, foster entrepreneurship, and boost access to financing, business development services, innovation, market access and cluster development (WIPO, 2013); and (4) the involvement of stakeholders' in policy-making and implementation (WIPO, 2014). Additionally, the three focus on addressing and providing a framework that gives solutions that can promote development of SMEs, innovations and competitiveness among SMEs.

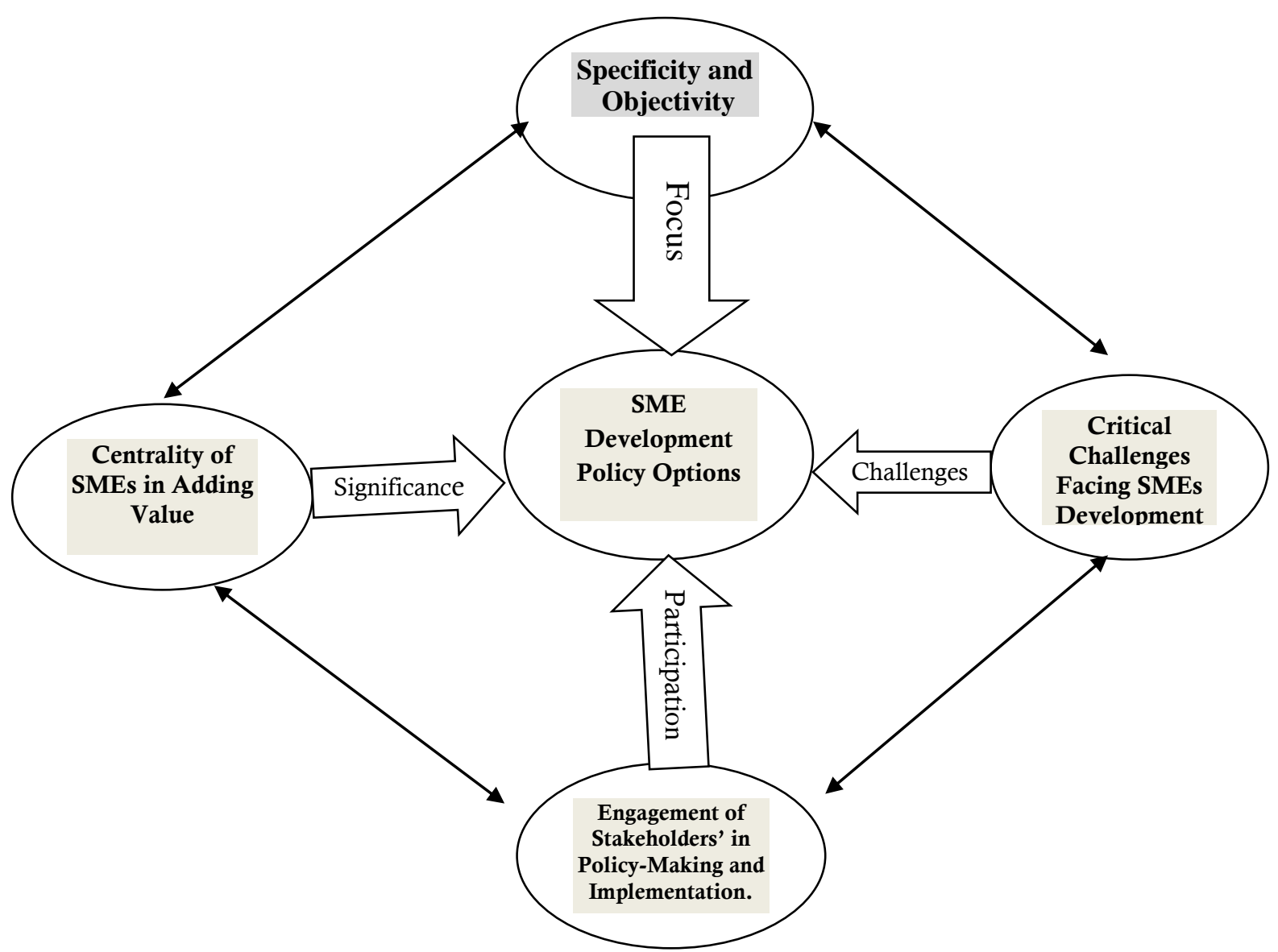

Figure 1: Framework for SME Development Policy Formulation Options

Source: Abe and Dutta (2014),

\section{Policy Quality and Focus}

According to Ikelegbe (2006), policy quality depends on how it is defined contextually. Public policy is a government action or poroposed action directed at achieving certain desired goals in light of a given societal problem (ibid). It should have the quality to guide and determines present and future public and private business institutional decisions or behaviour. Nduka et al (2010) assert that public policy is the strategic use of resources to alleviate national problems or governmental concerns with the interest in improving human conditions. A public policy can take different levels such as local district, council or national depending on the targeted scope (John and Mendizal, 2009). For a successful and quality policy, first, there is need to recognize the "real world" of policy making; any serious attempt to improve policy making needs to look at what has already been tried and the impact thereof (Simon, 1976; John and Mendizal, 2009). The policy skills framework emphasizes that policy is about "making change happen in the real world" (IFG, 2011). This concurs with Abe and Dutta (2014) and signifies the centrality of value addition for policy related to SMEs. Second, policy needs to adapt to new challenges (Nduka et al., 2010; Abe and Dutta, 2014; GoR, 2010). Third, have clear roles for government and other stakeholders to realize the policy (Michael et al., 2011). Fourth, a set of "policy fundamentals" that together constitute policy process (IFG, 2011), such as below: 


\begin{tabular}{|l|l|}
\hline \multicolumn{1}{|c|}{ Quality Area } & \multicolumn{1}{c|}{ Role Descriptions } \\
\hline Goals & $\begin{array}{l}\text { Has the issue been adequately defined and properly framed? How will the policy achieve the } \\
\text { high-level policy goals of the institution and the government as a whole? }\end{array}$ \\
\hline Ideas & $\begin{array}{l}\text { Has the policy process been of high quality and up to date? Have evaluations of previous } \\
\text { policies been done? Has there been an opportunity or license for innovative thinking? Have } \\
\text { policy makers sought out and analyzed ideas and experience from the other stakeholders? }\end{array}$ \\
\hline Design & $\begin{array}{l}\text { Policy makers: Have they rigorously tested/assessed whether the policy design is realistic, } \\
\text { involving implementers and end users? Have they addressed common implementation } \\
\text { problems? }\end{array}$ \\
\hline $\begin{array}{l}\text { External } \\
\text { engagement }\end{array}$ & $\begin{array}{l}\text { Have those affected by the policy been engaged in the process? Have policy makers identified } \\
\text { and responded reasonably to their views? }\end{array}$ \\
\hline Appraisal & $\begin{array}{l}\text { Have the options been robustly assessed? Are they cost-effective over the appropriate time } \\
\text { horizon? Are they resilient to changes in the external environment? Have the risks been } \\
\text { identified and weighed fairly against potential benefits? }\end{array}$ \\
\hline $\begin{array}{l}\text { Roles \& } \\
\text { Accountabilities }\end{array}$ & $\begin{array}{l}\text { Have policy makers judged the appropriate level of central government involvement? Is it } \\
\text { clear who is responsible for what, who will hold them to account, and how? }\end{array}$ \\
\hline $\begin{array}{l}\text { Feedback \& } \\
\text { evaluation }\end{array}$ & $\begin{array}{l}\text { Is there a realistic plan for obtaining timely feedback on how the policy is being realized? Does } \\
\text { the policy allow for effective evaluation, even if central government is not doing it? }\end{array}$ \\
\hline
\end{tabular}

Source: IFG (2011)

\section{The Centrality of SMEs in Adding Value in the Economy}

Historical data show evidences of the contribution of SMEs to developing economies. In Uganda, SMEs contributed more than $40 \%$ of the GDP; more than $50 \%$ to manufacturing and over $80 \%$ in wholesale and retail (Wangwe, 1999). In Zimbabwe, McPherson e, al., (1998) found that there were 860,000 SMEs outside agriculture and primary production employing 1.65 million people and a further 420,000 enterprises in agriculture and mining employing an additional 2.2 million people. A study in five African countries showed that small firms employing less than 10 workers accounted for 45-90\% of employment in manufacturing and 26-64\% of manufacturing value added (MVA) (Liedholm, 1990). A survey of growth in employment in three sub-Saharan Africa countries (Kenya, Ghana and Sierra Leone) shows that after the mid-1970s the growth of employment in Micro and Small Enterprises (MSEs) employing less than 50 workers outpaced that of medium and large-scale firms. The respective growth rates for MSEs and MLEs were 4.6\% and 2.4\% in the 1974-80 and $82 \%$ and $2.9 \%$ in the 1978-85 periods (ibid.). On the other hand, recent data amplifies the importance of SMEs globally. SMEs contribute to over $55 \%$ of GDP and over $65 \%$ of total employment in high-income countries (Hidayet et al., 2010). In middle income countries they contribute over $95 \%$ of employment and about $70 \%$ of GDP, moreover, they account for over $60 \%$ of GDP and over $70 \%$ of total employment in low-income countries (OEDC, 2004). Meghana et al., (2011) asserts a remarkable contribution of SMEs to both employment growth and incomes; whereas, employment opportunities created by the sector was growing at $10 \%$ per annum, the operators of the sector generate between 2.5 and 10 times the minimum earnings of civil servants. It is noted that SMEs and micro enterprises in OECD countries account for over $95 \%$ of all firms, $60-70 \%$ of employment and 55\% of GDP and create the majority of new jobs (ibid.).

According to UNIDO (2012), Tanzania has about three million SMEs employing more than 5.2 million people, with $45 \%$ of the employees based in urban areas and $55 \%$ in rural areas. Though data on SME is dominated by the informal sector; the sector has been decreasing over the years from $62.5 \%$ in 1991 to 43.6\% in 2005 and 39\% in 2010 (Informal Sector Survey, 1991; Matambalya, 2000; UNIDO, 2012). In Rwanda, the private sector employs over $90 \%$ of the Rwandan workforce and SME accounting for $41 \%$ of all private sector employment. SMEs are about $98 \%$ of all enterprises (formal and informal) and are providing $84 \%$ of private employment. It is also noted that only few enterprises are registered (EAC Business Assoc. Report, 2009). According to the Rwanda Business Operators Census Report (2009) on SMEs, the vast majority of SMEs (93.07\%) work in commerce and services. 
This is followed by $1.86 \%$ in professional services, $1.66 \%$ in Arts \& Crafts, $1.33 \%$ in industry, $0.94 \%$ in financial services, $0.7 \%$ in tourism and $0.45 \%$ in agriculture and livestock. On the other hand, despite the structure of a developed economies, there is evidence of the contribution of SMEs (Robu, 2014). SMEs in Japan contribute $38 \%$ of the GDP. In Italy, Ireland, Israel, Portugal, and Spain SMEs contribute between $35 \%$ and $50 \%$ of the GDP. The contribution of SMEs to economic fundamentals nonetheless varies substantially across countries: from 16\% of the GDP in low-income countries to $51 \%$ of the GDP in high-income countries (ibid.). According to Frimpong (2013), the contribution of the SME sector to the GDP in developing economies covers both the formal and informal sector, which is disproportionately large in low-income countries. Table 4 indicates the contribution of SMEs to different countries.

Table 5: Contribution of SMEs to different Economies

\begin{tabular}{|c|c|c|}
\hline Country & Index & Various Shares to the Economy \\
\hline United States & Less than 100 employees & $\begin{array}{l}38 \% \text { investment, } 50 \% \text { employment, } 65 \% \text { of GDP, } 32 \% \text { export, } \\
32.2 \% \text { total value added }\end{array}$ \\
\hline Japan & Less than 300 employees & $\begin{array}{l}99.4 \% \text { of all employee establishments, } 38 \% \text { total exports } \\
81.4 \% \text { of all employees, } 60 \% \text { of GDP, } 52 \% \text { value added }\end{array}$ \\
\hline Germany & Less than 10 employees & $\begin{array}{l}85 \% \text { of all companies, contribute } 52 \% \text { of GDP, } 64 \% \text { employment, } 31.1 \% \text { exports, } 44 \% \text { total } \\
\text { investment }\end{array}$ \\
\hline France & Less than 9 employees & $99.9 \%$ of all firms, $55 \%$ of GDP, $23 \%$ total exports \\
\hline $\begin{array}{l}\text { South Korea \& } \\
\text { China }\end{array}$ & Small industries & $\begin{array}{l}97.8 \% \text { of enterprises, } 60 \% \text { of GDP, } 61.9 \% \text { employment, } 35.7 \% \\
\text { of investment. China - } 99 \% \text { of employment, } 65 \% \text { of GDP }\end{array}$ \\
\hline Brazil & Small scale sector & $56.6 \%$ employment, $65 \%$ of GDP \\
\hline Tanzania & SMEs & Contribute more than a $33 \%$ of the GDP \\
\hline South Africa & SMEs & $\begin{array}{l}\text { make up } 91 \% \text { of formal businesses, contribute between } 52 \% \text { and } \\
57 \% \text { to GDP and } 61 \% \text { to employment. }\end{array}$ \\
\hline Rwanda & SMEs & $41 \%$ of private sector employment, $90 \%$ of all enterprises, $84 \%$ of self-employment \\
\hline
\end{tabular}

Source: Hidayet et al (2010), Robu (2013) and Frimpong (2013)

\section{Critical Challenges Facing SME Development}

SMEs enjoy dynamism, simplified management with lack of bureaucracy, their managers can react quickly to take advantage of new opportunities and are more willing to accept risk, they also have efficient and informal communication networks (Xhepa, 2006). SMEs informality provides ability to rapidly recognise and adapt to change in the external environment and afford a fast response to internal problem-solving (ibid.). However, there are varied challenges facing and limiting growth of SMEs in the context of developed and developing economies and they call for more efficient and professional government services to enhance SME competitiveness (OECD, 2012). Goodluck et al (2016) argues that, it is imperative for governments to recognise the importance of putting in place a national policy framework for SME development for addressing comprehensively the SMEs' capacity, innovation, statebusiness relations and competitiveness challenges.

There is wide literature on challenges facing SMEs at global, regional and national levels (Gamba, 2016; OECD, 2012). Further, SMEs challenges have been addressed based on the level of the development divide where developed and developing countries face different challenges and have varied mechanism of dealing with them (OECD, 2016). According to Xhepa (2006), SMEs globally and particularly in developing countries, Tanzania and Rwanda being not exceptional, face challenges such as: First, marketing; they lack ability to react quickly to keep abreast of fast-changing market requirements (GII, 2016). Second, qualified human capital; frequent lack of suitably qualified technical specialists and often unable to support formal R\&D and innovation efforts on an appreciable scale (GC1, 2016). Third, external communication; frequent lack of time or resources to identify and use important external sources of scientific and technological expertise. Fourth, finance and growth; there is great difficulty in attracting risk capital as innovation and growth represent a disproportionately large financial risk and acquiring external capital necessary to warrant rapid growth. Fifth, economies of scale and the systems approach; lack of economies of scale and inability to offer integrated product lines can form substantial entry barriers to SMEs. Sixth, Property Rights; SMEs can experience problems in coping with the patent system, they cannot afford time and costs involved in patent litigation and other 
related technical procedures based on international requirements (WIPO, 2015). Seventh, lack of reliable utility; electricity, water and other utilities are not only unreliable but also inedequate and of high cost. The alternative utilities such as generators, solar energy and drilled wells are all expensive. Eigth, government regulations; SMEs cannot cope with complex regulations so that unit costs of compliance for them become high. Handling such challenges would actually broadcast and whistle about the need of politically oriented frameworks for exploiting their underneath potential and aligning available resources and capabilities for economic development optimization (URT, 2003; GoR, 2010; Xhepa, 2006).

\section{The Engagement of Stakeholders' in Policy-Making and Implementation}

Considering the significance and challenges of SME sector in the economy, its stakeholders are large part of any economy. The engagement of stakeholders is crucial for aligning their commitments and accelerating impact and efficiency value delivery to the economy for both policy making and implementation (Fontanine et al, 2006; Jensen, 2001). Among the stakeholders are governments, development partners, civil society organizations, business associations, large and multi-national enterprises, education institutions, R\&D organizations and the general public to mention a few. The theoretical and empirical studies suggest that three stakeholders' attributes namely power, urgency and legitimacy guide the kind of actions on their stake (Yang et al., 2014). The stakeholders' ability and intention to threaten and cooperate was one set of the determinants of a successful policy initiative. Another set was the level of interest and power of stakeholders in influencing a policy initiative (Fontanine et al, 2006). Figure 2 presents the coherent strategic actions to various stakeholders during policy making and implementation.

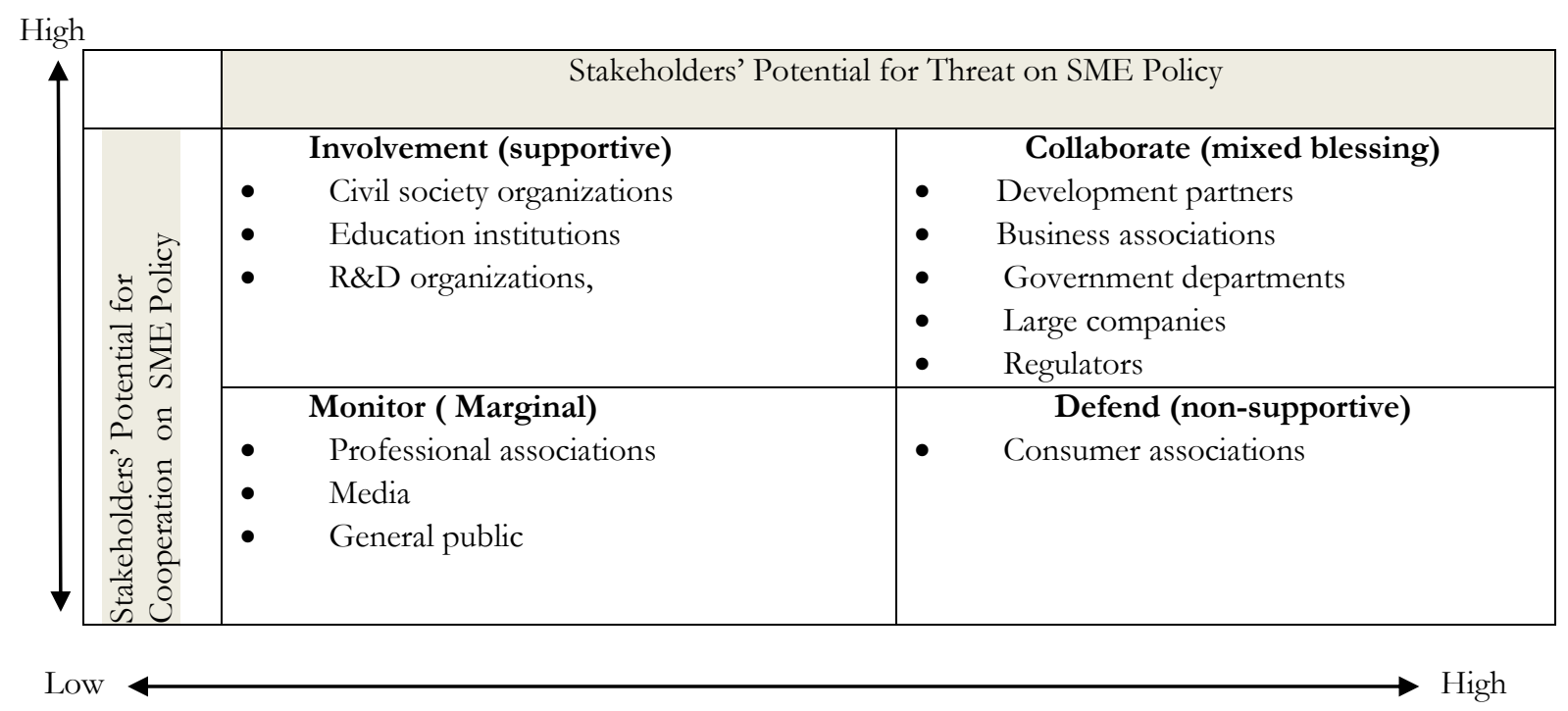

Figure 2: Stakeholders' Strategic Actions for Policy Making and Implementation

Source: Yang et al., (2014) and adopted for Relevance of SME Policy Framework

\section{Overview of SME Policy Frameworks of Tanzania and Rwanda}

The SME Development Policy 2003 is one of several policies that underpin Tanzania's Vision 2025 which envisions the following: "Tanzanians will have graduated from a least developed country to a middle income country by the year 2025 with a high level of human development and a shift from an agriculture-based to an industry-based economy. The Tanzania Government through a new planning paradigm based on its Five-Year Development Plans (FYDPs) running up to 2025 focusing on industrialization and pro-poor growth, by addressing supply constraints in key sectors with higher multiplier effects such as SMEs. The Tanzanian SME development policy structure revolves around seven pillars, namely: legal and regulatory framework, physical infrastructure, business development services (BDS), access to finance, and institutional framework for SME development, rural industrialisation and cross cutting issues. On the other hand, Rwanda's SME Sector face more or less the same challenges other developing countries face. A survey identified the challenges faced by SMEs 
as high taxes, under the current tax regime, lack of customer/market knowledge, lack of capital, uncompetitive prices, lack of access to finance as well as transport problems (RoR, 2010). Based on suitability, feasibility and acceptability factors, the five policy objectives were formulated in SME Policy (2010).

\section{Methodology}

This is purely a desk study. The extensive review of 132 annotated bibliographies on policy processes (Mooij and de Vos, 2003) and SME development policy documents in Rwanda and Tanzania between 2003 and 2015 was done. This being a comparison of two similar policies in two different countries, the policy content and context analysis based on SME policy comparators was employed (Abe and Dutta, 2014). These comparative parameters are (1) focus on SMEs; (2) the centrality of SMEs in adding value namely, significance; (3) critical challenges facing SMEs; and (4) the participation of stakeholders' in policy-making and implementation (ibid.). This method enabled the researcher to systematically investigate the effectiveness of policy documents presentations for anticipating interventions, implementation and acceptability by determining merit, worth, or value of the policy in terms of projected socio-economic impact.

The analysis was based on comparative parameters. First, the focus was generally searched from literature for establishing specificity, quality and objectivity. Second, the centrality of SMEs in adding value included the comparative historical data showing evidence of the socio-economic contributions of SMEs in the countries under review. The arguments and evidence were compared for validation and rationalization of the SME development policy. Third, critical challenges facing SMEs were compared between the two countries depending on the number, clarity, classifications and targets. The understanding of challenges supports development of focused policy statements, strategies and solutions for achieving the policy vision and mission. Fourth, the involvement of stakeholders' in policy-making and implementation was compared based on stakeholders typlogy matrix (Jensen, 2001; Yang et al.,2014). The stakehlders typology helps to assess whether all stakeholders such as those who have natural and/or institutional obligation of being collaborative, involving, monitoring and defending participate in the policy processes. On the whole, the comparison of policy vision and mission, development rationale, background arguments, the comparators statistics, regulatory and institutional choices were analysed. The presentation of the analysis follows the same patterns of comparator parameters and include general information on the analyisis of SME Developemt Policy Frameworks in Rwanda and Tanzania for giving a snapshot of policy ingredients including the summarized national SME policy objectives of each country and declares areas of differences between the two policies.

\section{Findings}

\section{General findings on SME policy Frameworks and Presentations}

National policy framework for SME development in Rwanda and Tanzania differs. First, as the Rwanda policy begins with specificity by addressing the national issue; the Tanzanian policy begins with the general introduction. The issue straightens focus and catches the attention and energy of actors as it is included in the vision and specifies the policy mission i.e. "achieve an annual GDP growth rate of 8.1 percent increasing the off-farm employment and tax revenue". Second, the Rwandan policy portrays the strategy for achieving the desired policy outcome i.e. "priority sector and business cluster development". The Tanzanian policy does not mention a critical issue and a clear national strategy for guiding actors' focus on SME sector development. Third, the Tanzanian policy does not present the country situation adequately. It does not provide statistics and studies performed for policy rationalisation. Rwanda provides base documents and statistics for the policy rationalization; the policy shows that it was based on international research on policy practices from which selection and contextualization of best practices was done. Fourth, in Rwanda, other national policies and strategies are interacting with the SME policy targeting competitiveness as a unifying factor. Additionally, for enabling synergy, some policies were formulated concurrently with SME policy. Fifth, the policy priority sectors and business clusters were 
identified, categorized, visualized and referenced throughout the Rwanda policy document. Sixth, criteria for preferred policy objective and selection of implementing institutions were established and abided to in Rwanda; this means that every policy objective and implementing institutions were subjected to pass through a criteria test of suitability, feasibility and acceptability. Though it was not exercised in Tanzania, it signifies commitment and intention to efficient allocation of resources.

Furthermore, the Tanzanian policy was launched in 2003, therefore it is old and outdated whereas Rwandan policy of 2010 is relatively current. The relative newness of Rwanda SME Developmet Policy 2010 enabled it to be more sharp, coherent and holistic than that of Tanzania. The wording of vision and mission statements of Rwandan policy were more active, strategically ambitious, soliciting committment and energizing stakeholders than that of Tanzanian policy. For example, the Rwanda vision is "to create a critical mass of viable and dynamic SMEs significantly contributing ... " Tanzanian vision is "to have a vibrant and dynamic SME sector that ensures effective utilisation of available resources ..". This could be reasonated by the fact that during policy formulation in Rwanda, Tanzanian SME policy was used as a case study.

\section{Findings on Policy Focus on SME Specificity}

The Tanzanian policy presentation shows only pillars 3 and 5 and partly pillar 4 are SME specific while all objectives are SME specific in the Rwandan policy (see figure 3). In Tanzania pillars such as Business Development Services (BDS) and Institutional Framework for SME Development Legal and Regulatory Framework are the only ones that are specific for SMEs. Pillars such as Physical Infrastructure, Access to Finance, Rural Industrialisation and Cross Cutting Issues are general issues and not specific to SMEs. In Rwanda issues not specific to SMEs but affecting them are addressed with other policies laws and strategies so as support SME policy implementation in a coordinated manner. Moreover, in terms of policy objectives, the Rwandan objective 1 is very crucial for establishing foundations for SMEs startups and growth in a sense that it addresses issues of mindset and attitude. This objective underscores the fact that entrepreneurship can be done by formally and informally-educated, non-educated and vulnerable groups. It is observed that Rwanda policy facilitated the establishment of National Young Entrepreneurs Schemes (NYES) and BDS centres. The Rwandan policy underscores the importance of mentoring programmes, succession planning, and use of successful entrepreneurs as models for entrepreneurial and business ideas generation. Strategies like talks and story-telling to children by government and private sector leaders on entrepreneurship and business related topics are devised to instigate right entrepreneurship culture. Furthermore, the Rwandan policy addresses promoting innovation and technical capacity of SMEs for competitiveness, which can be the result of improved Rwandan competitiveness in the global indices (GCI, 2016; GII, 2016). On the high level policy objectives, Tanzanian policy lacked areas of priority and silently show exclusion of new SMEs by insisting on improving the performance and competitiveness of the existing enterprises. This triggers negative policy implications, for example, access to financial services for new enterprises has been practically difficult. On the other hand, Rwandan high policy level objective determines and promotes priority sectors (especially off-farm) and clusters and gives equal chance to new and existing enterprises (RoR, 2010. p.8).

On the key policy objectives, it is found that the Tanzanian policy ignored the mindset or entrepreneurship culture transformation although this was included in the implementation matrix, thus missing focused policy statement. It is also observed that mostly legal binding issues were given more weight in Tanzanian policy. The innovation and competitiveness seen in the high level policy objective were not found in the implementation base of policy objectives. Moreover, in Rwanda rewarding of entrepreneurship was emphasized and honest entrepreneurs facing problems were given a second chance and not enforcing bankruptcy procedures. This created risk-free experimental ground for new entrepreneurs. Moreover, special and vulnerable groups were not targeted and mentioned in the Tanzanian policy as it was in the Rwandan policy. 


\section{Findings on Centrality of SMEs in Adding Value}

Both policies addressed centrality of SMEs in adding value. The potential of SMEs in adding value in Rwanda was more explicitly and strategically addressed than in Tanzania by identifying and prioritizing the most value adding sectors and business lines (RoR, 2010). These prioritized sectors for Rwanda were (1) Specialized Tourism, (2) Sericulture: silk and bamboo products, (3) Agro-processing: fruits and vegetables, cassava, irish potatoes, cooking oil, tomatoes, maize, wheat, (4) ICT Services: software development, back office operations, call centres, (5) Dairy Products: creation of cheese marketing company from cooperatives linked to the "one-cow-per family" programme, (6) Essential Oils: pyrethrum, jetropha, (7) Light Metal Industries: production of small spare parts and electric motors, etc. (8) Creative Industries: film, cultural shows, music, handcrafts and mining. On the other hand, Tanzania's policy emphasized the general importance of SMEs in Tanzania but did not present focused areas and priority sectors of SMEs for value addition. This shows a lack of focus on centrality of value addition (Abe and Dutta, 2014).

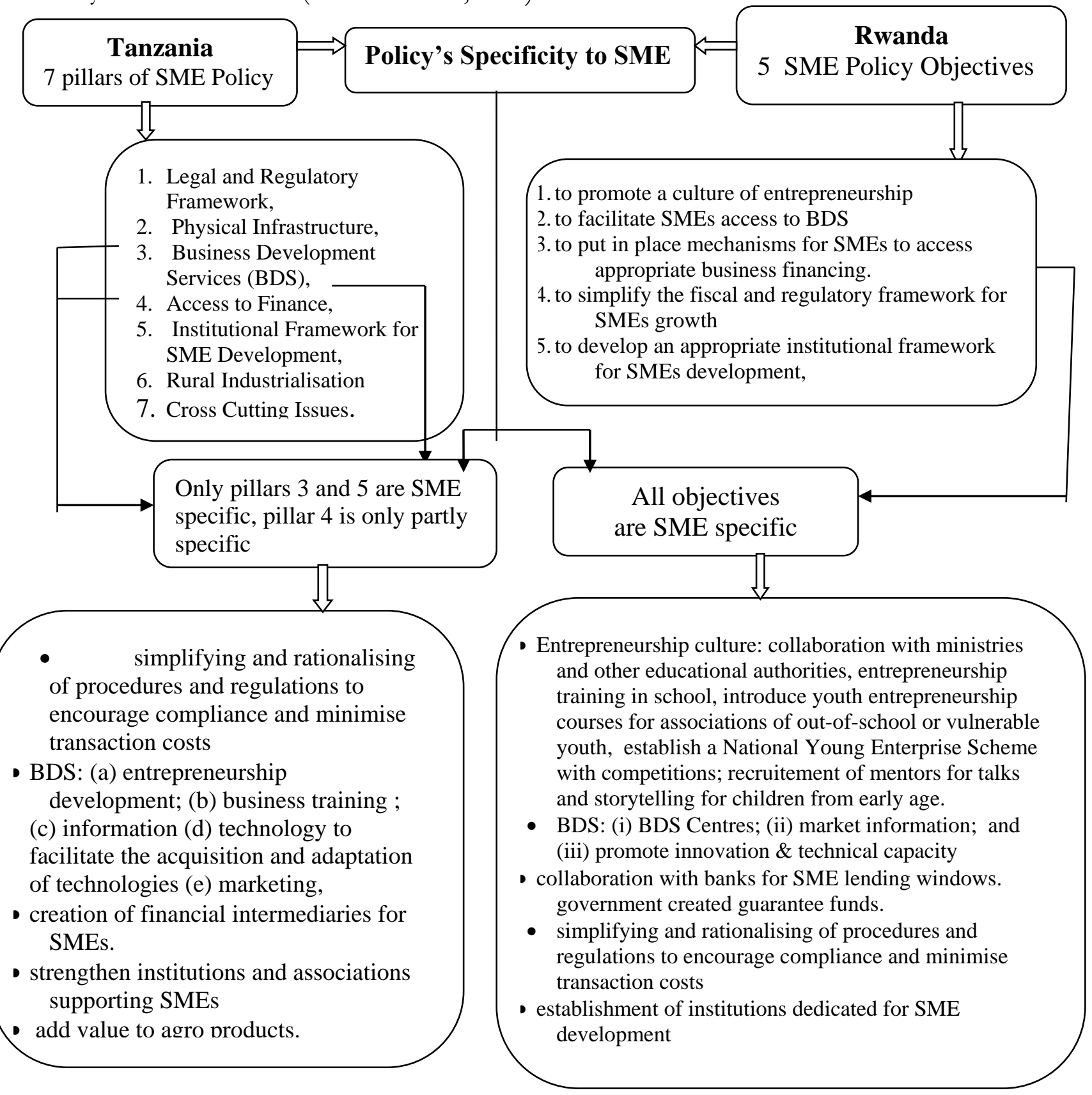

Figure 3: SME Development Policy Frameworks of Tanzania and Rwanda Source: Author, 2018 


\section{Findings on Critical Challenges in SME Development}

The critical challenges were addressed for creation of an enabling environment, foster entrepreneurship, and boost access to resources and capabilities for SMEs. Whereas, the Tanzanian policy itemized the general challenges facing SMEs, the Rwanda policy is articulative, spilling out separately the general challenges for both large and small firms and further dwelled into specific for SMEs and more by differentiating challenges facing existing SMEs and those facing new (start ups) SMEs. For start ups, challenges were lack of entrepreneurial culture, limited technical and business skills, and limited Business Development Services (BDS). For Scale-ups, high cost of doing business, lack of access to finance, difficulty accessing market information and markets were registered as key challenges. The SME policy addresses all of these concerns with the exception of transport and uncompetitive pricing, as they are macro-issues. The Rwanda approach of addressing challenges enabled avoidance of duplication of works and resources and integration of institutions during implementation, monitoring and evaluation. The formation of professional Business Associations (BAs) in Rwanda under the Private Sector Foundation of Rwanda (PSF) so as to research, mentor and consult for providing proven solutions for cluster specific challenges was the offspring of categorized challenges analysis. This though has not become a panacea, it has been a continuous partnership model between the private sector, professionals/experts, learning and research and other government institutions in Rwanda.

\section{Findings on Analysis of Stakeholders participation}

There is low involvement of monitoring institutions/stakeholders with low potential to cooperate and low potential for threat in both countries. Such institutions are professional associations, media and the general public. It is observed that there is heavy collaboration and involvement of government institutions such as ministries, department, regulators and agencies. Though consumer protection for policies and systems improvement is documented in policies (JICA, 2003; URT, 2003; GoR, 2010), policy presentations show that no consumer associations were involved in both countries neither in policy development nor in implementation. Figures 3 and 4 show the stakeholders' involvement, collaboration, monitoring and defending roles in the SME policy processes in Rwanda and Tanzania.

\section{RWANDA}

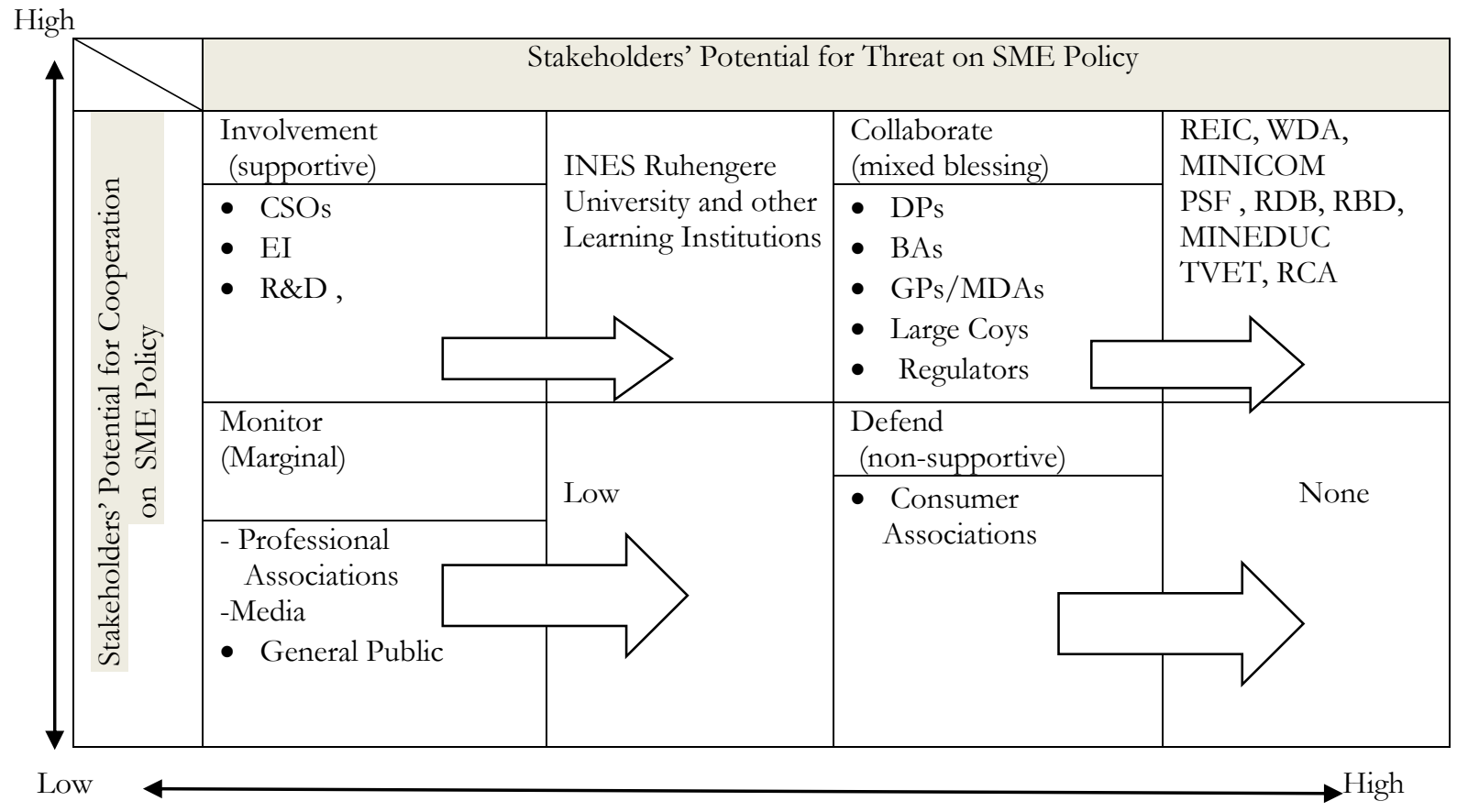

Figure 3: Rwanda Stakeholders' Participation for Policy Making and Implementation

Source: Author (2018): A construct from RoR (2010) and Yang et al., (2014) 


\section{TANZANIA}

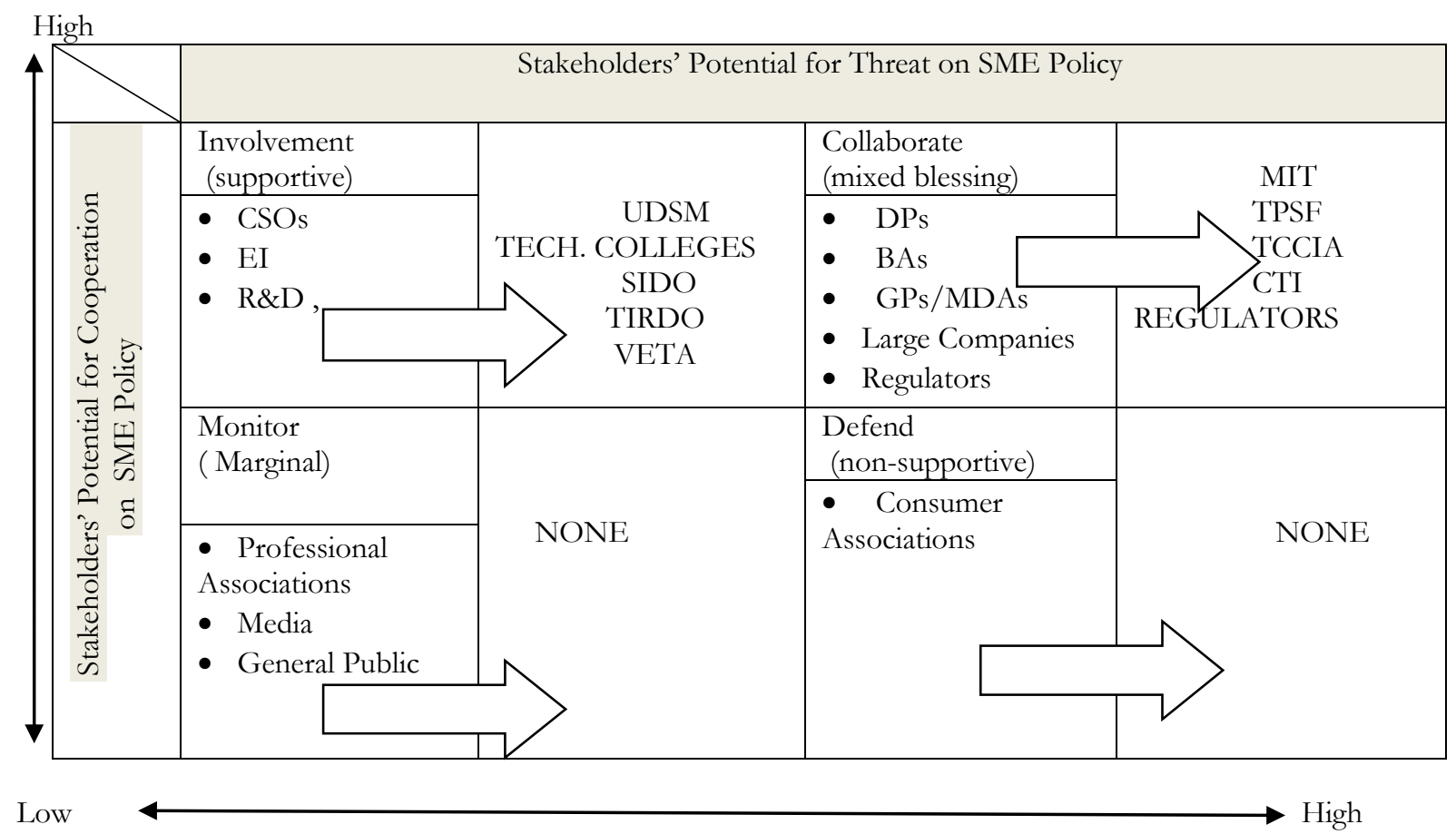

Figure 4: Tanzania Stakeholders' Participation for Policy Making and Implementation Source: Author (2018): A construct from URT (2003), Policy and Yang et al., (2014)

\section{Conclusion and Policy Implication}

First, the general findings show a difference between national policy framework for SME Development in Rwanda and Tanzania. Overall, the Rwandan policy attract more catch than that of Tanzania; the difference shows in various spheres of the policies including the SME definition, policy vision, mission, high level objectives and key policy objectives in terms of active presentation, political flavour, sharpness of intent and sense of anticipated commitment. Rwandan policy promotes strategic inclusion of new and existing SMEs whereas, Tanzanian policy indicates silent exclusion of new SMEs.

Second, for the centrality of SMEs in adding value in the economy; the Tanzanian policy does not present the country situation adequately, it does not provide issues based statistics and studies performed for its rationalisation. Rwanda SME Development policy shows that it was based on international research on policy practices and provides base documents and statistics for the policy rationalization from which selection and contextualization of best practices was done.

Third, in terms of challenges, it is concluded that Rwanda policy is articulative, diverse and integrative. It spells out separately the general challenges for both large and small firms and further dwelled into specifics for SMEs and more by differentiating challenges facing existing (scale-ups) SMEs and those facing new (start ups) SMEs. The Rwanda approach of addressing challenges enabled avoidance of duplication of works and resources and integration of institutions during implementation, monitoring and evaluation. It is recommended that categorical analysis of challenges and issues need to be underataken for formulating viable policy objectives, statements, and in devising strategies and sustainable solutions.

Fourth, in terms of stakeholders participation, defending and monitoring stakeholders were completely disengaged in SME policy issues in Tanzania, whereas, there was low engagement of 
monitoring stakehoders and none participation of defending stakeholders such as consumer associations in Rwandan SME Development policy. Rampantly, supportive and mixed-blessing stakeholders were used in both countries; these are mainly governmental departments, development partners and quasigovernmental institutions. Though, policy formulation and implementation are continuous government endeavours in all countries, it was observed that in both countries under review, there were no specific ministries identified to be responsible for policy formulation, coordination and integrating various national and sector policies. It is recomended to have a central organ for coordination of policy issues.

The policy implication of the findings and conlusion of this paper is beyond Tanzania and Rwanda and implies a sustainable SME development gap between EAC member countries until policies affecting SMEs are harmonized. Countries face issues such as varied definitions of SMEs and lack of uniformity of SME policy format. This scenario is also visible in many regional economic cooperation endeavours; where individual countries retain some aspects of their advantage outside cooperative mechanisms. In view of the economic cooperation with the objective of expanded market, the SME development policies are the stepping stones to market unification and regional competitiveness as it engulfs largest populations, involves all economic sectors, and is dynamic enough to make environmental adaptation decisions and integrate the cross-cutting diversity. The study as well implies that learning policy issues of a prominent sector like SME triggers understanding of critical areas for value addition, challenges and harmonization which could attract intensive cooperation and win-win socio-economic relationships between countries.

\section{$\underline{\text { References }}$}

Abe, M. and M. Dutta (2014m February). A New Policy Framework for Myanmar's SME Development. Working Paper No. 142

Agalo, V. (2010). Informal Cross Border Trade in East African Community: Implications for

Regional Integration and Development. CUTS Africa Resource Centre, Nairobi

Fontanine, C., Haarman. A and S. Schmid. (2006). The Stakeholder Theory. (Accessed on 12 November, 20107) from http:// www.pdfs.semanticscholar.org

Gamba, J. F. (2016). Contribution of Selected Business Associations to the Performance of Food Processing SME's In Rwanda and Tanzania. European Journal of Business Management. Vol. 5 (11). Pp 65-88.

Gamba, J. F. (2017). Facilitating Innovation in Developing Countries: Challenges and Choices

The African Journal of Finance and Management - Vol. 26 No. 1: 40-51

GCI (2016) www.weforum.org (Accessed on $5^{\text {th }}$ March, 2017)

GII, (2015). Effective Innovation Policies for Development at http://www.wipo.int/publications

(Accessed on 2nd January, 2017)

GII, (2014). The Human Factor in Innovation at http://www.wipo.int/publications/en. (Accessed on 2nd January, 2017)

GII, (2013). The Local Dynamics of Innovation at http://www.wipo.int/publications/en

(Accessed on 2nd January, 2017)

Goodluck, C., Jeppesen, S., Kamau, P and P. Kragelund (2016). Firm-level Perspective on State-

Business Relations in africa: the food processing industry in Kenya, Tanzania and Zambia,

Forum for Development studies. DOI:10:1080/08039410. 2016. 1252425

GTZ-EAC (2009). Study on the Future Strategy of Cooperation with East African Business

Associations to contribute to the EAC Integration Process.

Hidayet, K., Canan, S., Onur, S. \& M. Hakan (2010). The Importance of SMEs in Developing

Economies. 2nd International Symposium on Sustainable Development June 8-9 Sarajevo.

Horowitz Donald, L. (1989). "Is there a Third World Policy Process?” Policy Sciences, Vol. 22,

No.3-4 pp. 197-212

Institute of Government (2011). Better Policy Making. www.instituteforgovernment.org.uk. (Accessed on $9 / 4 / 2018)$ 
Jensen, M.C. (2001). Value Maximization, Stakeholders Theory, and the Corporate Objectives Function. European Financial Management, Vol.7, No.3 297-317

John. Y, \& E. Mendizal (2009) helping reserachers become policy entrepreneurs, Overseas Development Institute, London. September

Lucacs, E. (2005), The economic role of SMEs in World Economy, Especially in Euroupe, European Integration Studies, Miskolic, Volume 4, No.1, pp 3-12

Maad, D. C., \& C. Liedholm (2008). The dynamics of micro and small enterprises in developing countries. Journal of Finance, 26 (1): 61-74.

Matambalya, F. (2000). The Significance of ICTs for economic productivity in Africa. A Micro level evidences from a survey of SMEs in Tanzania. Internationales. Afrikaforum, No.3.273-280.

Meghana, A., Asli, D. \& V. Maksimovic (2011). Small vs. Young Firms across the World Contribution to Employment, Job Creation and Growth, p.2-3, http://www.rhsmith.umd.edu/cfp/pdfs docs/papers/Max2.pdf (Accessed on 10th Sept, 2015)

Michael, H., Simon, P. \& R. Jill (2011). Policy Making in the Real World, Institute for Government Chapter 2 from www.instituteforgovernment.org.uk. (Accessed on 9/4/2018)

Miles, S. (2012). "Stakeholders: essentially contested or just confused?" Journal of Business Ethics. 108(3): 285-298. doi: 10.1007/s10551-011-1090-8

Miles, S. (2011). "Stakeholders Definitions: Profusion and Confusion. IE ASM 1" Interdisciplinary conference on stakeholder, resources and value creation, IESE Business School, University of Navarra, Barcelona.

Mitroff, I. (1883). Stakeholders of the Organisational Mind. San Francisco

OECD. 2003. R\&D tax incentives: rationale, design, evaluation. OECD Innovation Policy Platform. Paris: Organisation for Economic Cooperation and Development. Available at: http://www.oecd.org/dataoecd/32/37/48141363.pdf (Accessed on $2^{\text {nd }}$ April, 2017)

Mooij ,J. \& de V. Vos (2003). Annotated Bibliographies on Policy Processes. ODI Working Paper 221: $1-68$

OECD (2007), Innovation and Growth: Rationale for an Innovation Strategy Available at: http://www.oecd.org/dataoecd. (Accessed on $2^{\text {nd }}$ April, 2017)

OECD (2012), Innovation for Development: a discussion of the issues and an overview of work of the OECD directorate for science, technology and industry. Available at: http://www.oecd.org/dataoecd (Accessed on $2^{\text {nd }}$ April, 2017)

Osei, B., Baah-Nuakoh, A., Tuku, K. \& N. Sowa. (1993). Impact of Structural Adjustment on Small-Scale Enterprises in Ghana. Journal of Small Business Management 38 (4): 42-58

Pitman, F. (2008). Internet cafe entrepreneurs: pioneers in information dissemination in Indonesia. The International Journal of Entrepreneurship and Innovation, 4(4): 251-263.

Swierczek, F. \& Ha, T. (2007). Entrepreneurial orientation uncertainty avoidance and firm performance: an analysis of Thai and Vietnamese SMEs. International Journal of Entrepreneurship and Innovation, 4(1):46-58.

Republic of Kenya, (2010). Kenya Vision 2030. www.vision2030.go.ke. (Accessed on 12/9/2017)

Republic of Rwanda, (2010). Rwanda SME Development Policy 2010, Ministry of Industry and Trade

Republic of Rwanda (2012). Review of Rwanda Vision 2020 at www.gov.rw. (Accessed 17/3/ 2016)

Republic of Rwanda (2009). Prioritized SME Clusters, Ministry of Industry and Trade

Republic of Rwanda (2009). Rwanda Business Operators Census Report, Ministry of Industry and Trade

Republic of Rwanda (2008). OTF/PSF survey, Ministry of Industry and Trade

Robert, P. (2003). Stakeholders Theory and Organisational Ethics. ISBN 1576752682

Simon, H (1976). Administrative Behaviour ( $3^{\text {rd }}$ ed.). New York: The Free Press. ISBN 0-684- 
83582-7

Thomas, I (2007). Environmental policy: Australian Practice in the context of theory. Sydney:

Federation Press. ISBN 1-86287-603-7.

UNIDO (2012). Tanzania SME Development Policy 2003, “Ten Year After” Implementation Review.

URT (2012b). Micro, Small and Medium Enterprises in Tanzania, National Baseline Survey Report, Ministry of Trade and Industry and Financial Sector Deepening Trust, Dar es Salaam URT (2003). Tanzania SME Development Policy, 2003. Mkukuta II, NDV 2025, Kilimo

KWANZA. www.tanzania.go.tz . (Accessed April, 2012).

Verhees, F. \& M. Muhlenberg (2009). Market Orientation, Innovativeness, Product Innovation, and Performance in Small Firms. Journal of Small Business Management, 42(2):25-38.

Wangwe, S. (1999). Micro and Small Enterprises Development and Employment Implications: Review of Current Status and Prospects; ILO-ESRF Round Table.

Xhepa, S. (2006), Competitiveness and the SME Development in Albania, The Institute for Contemporary Studies (ISB), Tirana. http://www.westernbalkans.info/upload/docs/1 Albania_SMEnew.pdf]. 2nd International Symposium on Sustainable Development, June 89 2010, Sarajevo 192 .(Accessed on 22 November, 2017).

Yang, R, Wang, Y. \& X. Jin (2014). Stakeholders' Attributes, Behaviour, and Decision Making strategies in Construction Projects: Importance and Correlations in Practice. Project Management Journal, 45: 74-90. doi:10.1002/pmj.21412 